\title{
ANALISIS FAKTOR YANG MEMPENGARUHI ALIH FUNGSI LAHAN SAWAH KE NON SAWAH DI KABUPATEN SLEMAN DAERAH ISTIMEWA YOGYAKARTA
}

\author{
Annisa Titias Habibatussolikhah ${ }^{1}$, Darsono ${ }^{2}$, Susi Wuri Ani ${ }^{3}$ \\ 1. Mahasiswa Program Studi Agribisnis Fakultas Pertania Universitas Sebelas Maret Surakarta \\ 2. Dosen Pembimbing Utama \\ 3. Dosen Pembimbing Pendamping \\ Program Studi Agribisnis Fakultas Pertanian Universitas Sebelas Maret Surakarta \\ E-mail : annisatitias@gmail.com
}

\begin{abstract}
The development of non-agricultural sector are increasingly in need of land. The land needs met by conversion of agricultural land to non-agricultural land. This research was aimed to examine the rate of the agriculture land (wet land) conversion and factors that determine the conversion in Sleman Regency. The basic method which used was descriptive analytic. Determination of the research location was using purposive method in Sleman regency. Method to analyze the data was double linear regression (Ordinary Least Square). The data which used in this research was secondary data in 1984-2013 from BPS, BPN, Bappeda, and DPUP of sleman regency.The result of this research shows that the conversion of wet land in Sleman regency happened in 1984-2013. Since 30 years, wet land area which convert to nonagricultural area was $4.496 \mathrm{Ha}$ or $150 \mathrm{Ha}$. Wet land area had decreased with the growth rate 0,608\% per year. Based on the double linear regression analysis (Ordinary Least Square) with 95\% of trust level, it could be known the significance relation between wet land area and the number of population, industry, residential, road length, PDRB, and government policy. Individually, the area of agricultural land in sleman regency was influenced by the number of population, industry, residential, and PDRB.
\end{abstract}

Keywords: Land Conversion, Wet Land, Non Agriculture Land, and Non Agriculture Sector.

\begin{abstract}
Abstrak: Perkembangan sektor non pertanian yang semakin meningkat membutuhkan lahan. Kebutuhan lahan tersebut dipenuhi dengan melakukan alih fungsi lahan pertanian ke lahan non pertanian. Penelitian ini bertujuan untuk mengkaji perkembangan alih fungsi lahan sawah ke non sawah dan mengkaji faktor-faktor yang mempengaruhi alih fungsi lahan sawah ke non sawah di Kabupaten Sleman. Metode dasar yang digunakan adalah deskriptif analitis.Penentuan lokasi penelitian dilakukan secara purposive di Kabupaten Sleman. Metode analisis data yang digunakan adalah analisis regresi linear berganda berbasis OLS (Ordinary Least Square). Jenis data yang digunakan adalah data sekunder tahun 1984-2013 yang bersumber dari BPS, BPN, Bappeda, DPUP Kabupaten Sleman. Hasil penelitian menunjukan bahwa terjadi alih fungsi lahan sawah di Kabupaten Sleman tahun 1984-2013 sebesar 4.496 Ha. Luas lahan sawah menurun tiap tahun sebesar $0,608 \%$. Berdasarkan hasil analisis regresi linear berganda (Ordinary Least Square) dengan taraf kepercayaan 95\% diketahui adanya pengaruh signifikan antara variabel dependen luas lahan sawah dengan variabel independen jumlah penduduk, jumlah industri, jumlah residential, panjang jalan dan Pendapatan Domestik Regional Bruto (PDRB). Secara individu variabel dependen luas lahan sawah di Kabupaten Sleman dipengaruhi oleh variabel independen jumlah penduduk, jumlah industri, jumlah residential, dan PDRB.
\end{abstract}


Kata Kunci : alih fungsi gahan, lahan sawah, lahan non sawah, dan sektor non pertanian.

\section{PENDAHULUAN}

Indonesia merupakan negara agraris di mana pertanian merupakan basis utama perekonomian nasional. Alih fungsi lahan pertanian merupakan dampak dari transformasi struktur ekonomi (pertanian ke industri), dan demografi (pedesaan ke perkotaan) yang pada akhirnya mendorong transformasi sumber daya lahan dari sektor pertanian ke non pertanian. Alih fungsi lahan pertanian ke sektor non pertanian secara teoritis dapat dijelaskan dalam konteks ekonomika lahan yang menempatkan sumberdaya lahan sebagai faktor produksi, kemudian secara alamiah akan terjadi persaingan dalam penggunaan lahan untuk aktifitas pertanian dan aktifitas industri. Gejala alih fungsi lahan dari lahan sawah menjadi lahan non sawah semakin meningkat, khususnya bagi suatu kota atau wilayah yang berpenduduk lebih dari satu juta jiwa. Gejala ini cenderung terjadi di desa-desa di wilayah pinggiran kota di mana lahan persawahan masih tersedia cukup luas (Bachriadi, 1997).

Dampak alih fungsi lahan terhadap eksistensi lahan sawah berlangsung cepat dan nyata. Menurut Irawan (2005), Semakin sedikit lahan sawah maka semakin sedikit ketersediaan bahan pangan. Di sisi lain tiap tahun pertumbuhan penduduk semakin meningkat. Pembukaan lahan sawah baru pun belum bisa menggantikan jumlah produksi akibat alih fungsi lahan pertanian. Jika ini terus berlanjut maka akan mengganggu swasembada beras yang berdampak pada ketahanan pangan.

\section{METODE PENELITIAN}

Metode yang digunakan dalam penelitian ini adalah metode deskriptif analitis. Menurut Nazir (2003), metode deskriptif adalah suatu metode dalam meneliti status kelompok manusia, suatu objek, suatu set kondisi, suatu pemikiran, ataupun suatu kelas peristiwa pada masa sekarang.Lokasi tempat penelitian dipilih secara sengaja (purposive), yaitu memilih objek karena alasan-alasan tertentu yang telah diketahui (Surakhmad, 2004). Penelitian inidilakukan di 17 kecamatan yang berada di Kabupaten Sleman Daerah Istimewa
Yogyakarta. Jenis data yang digunakan adalah data deret waktu (time series) berupa data tahunan dari tahun 1984 hingga 2013.

\section{Metode Analisis Data}

Analisis yang digunakan dalam penelitan ini, yaitu:

1. Perkembangan alih fungsi lahan sawah

2. Pendekatan pertumbuhan luas lahan sawah (Sjafrizal, 2014).

$\mathrm{r}=\mathrm{L}_{\mathrm{t}}-\mathrm{L}_{\mathrm{t}-1} / \mathrm{L}_{\mathrm{t}} \mathrm{x} 100 \%$

Keterangan:

$\mathrm{L}_{\mathrm{t}}=$ Luas lahan sawah tahun ke-t (Ha)

$\mathrm{L}_{\mathrm{t}-1}=$ Luas lahan sawah tahun sebelumnya

(Ha)

3. Regresi linear berganda (Gujarati dalam Ghozali, 2011).

$$
\begin{aligned}
\operatorname{Ln} Y_{t}= & \operatorname{Ln} \beta+\operatorname{Ln} \beta_{1} X_{1}+\operatorname{Ln} \beta_{2} X_{2}+\operatorname{Ln} \beta_{3} X_{3}+ \\
& \operatorname{Ln} \beta_{4} X_{4}+\operatorname{Ln} \beta_{5} X_{5}+\operatorname{Ln} \beta_{6} X_{6}+D
\end{aligned}
$$

$$
\begin{aligned}
& \text { Keterangan: } \\
& \mathrm{Y}_{\mathrm{t}} \quad=\text { Perubahan luas lahan } \\
& \text { sawah(Ha) } \\
& \beta=\text { Konstanta } \\
& \beta_{1}, \ldots, \beta_{6}=\text { Koefisien regresi } \\
& \mathrm{X}_{1} \quad=\text { Jumlah penduduk } \\
& \text { (jiwa) } \\
& \mathrm{X}_{2} \quad=\text { Jumlah industri (buah) } \\
& \mathrm{X}_{3} \quad=\text { Jumlah residential (unit) } \\
& \mathrm{X}_{4} \quad=\text { Panjang jalan }(\mathrm{km}) \\
& \mathrm{X}_{5} \quad=\text { PDRB (jutaan rupiah) } \\
& \mathrm{D}_{\mathrm{t}} \quad=\text { Kebijakan pemerintah }
\end{aligned}
$$

\section{HASIL DAN PEMBAHASAN}

\section{Kondisi Umum Lokasi Penelitian}

Penelitian dilakukan di Kabupaten Sleman. Kabupaten Sleman adalah salah satu Kabupaten yang ada di Daerah Istimewa Yogyakarta. Kabupaten Sleman secara geografis terbentang mulai $110^{\circ} 13^{\prime} 00^{\prime}$ " sampai dengan $110^{\circ} 33^{\prime}$ ' 00" Bujur Timur (BT) dan mulai $7^{0} 34^{\prime}$ '51" sampai dengan $7^{\circ} 47$ '03" Lintang Selatan (LS), dengan ketinggian antara 100-2500 meter di atas permukaan laut (mdpl). 
Annisa Titias H., Darsono dan Susi Wuri A.: Analisis Faktor Yang Mempengaruhi ....

Tabel 1. Pertumbuhan Luas Lahan Sawah di Kabupaten Sleman Tahun 1984-2013

\begin{tabular}{ccc}
\hline Tahun & $\begin{array}{c}\text { Luas Lahan Sawah } \\
(\mathrm{Ha})\end{array}$ & Pertumbuhan Lahan Sawah(\%) \\
\hline 1984 & 26.901 & -0.810 \\
1992 & 25.438 & -0.719 \\
1999 & 24.291 & -0.123 \\
2006 & 23.121 & -0.302 \\
2013 & 22.623 & 0.159 \\
\hline Rata-rata & $24.372,333$ & $-0,608$ \\
\hline
\end{tabular}

Sumber: Kabupaten Sleman dalam Angka, 1985-2014 (diolah)

\section{Topografi}

Keadaan tanah Kabupaten Sleman di bagian selatan relatif datar kecuali daerah perbukitan dibagian tenggara Kecamatan Prambanan dan sebagian Kecamatan Gamping. Semakin ke utara relatif miring dan dibagian utara Lereng Merapi relatif terjal serta terdapat sekitar 100 sumber mata air. Beberapa sungai yang mengalir melalui Kabupaten Sleman antara lain Sungai Progo, Krasak, Sempor, Kuning, Boyong, Winongo, Gendol, dan Opak. Hampir setengah luas wilayah merupakan wilayah pertanian yang subur dengan didukung irigasi teknis dibagian barat dan selatan. Topografi dapat dibedakan atas dasar ketinggian tempat dan kemiringan lahan atau lereng (BPS, 2014).

\section{Tata Guna Lahan}

Hampir setengah dari luas wilayah Kabupaten Sleman merupakan lahan pertanian yang subur didukung irigasi teknis di bagian barat dan selatan. Keadaan jenis lahan dibedakan atas lahan sawah, tegal, pekarangan, hutan, dan lain-lain.penggunaan lahan pekarangan (house compounds) sebesar 18.590,90 Ha, sawah (wet land) 24.719,05 Ha, tegal (dry land) 3.923,69 $\mathrm{Ha}$, hutan (forest) $52,99 \mathrm{Ha}$, tanah tandus dan semak (barren and bush) 1.263,84 Ha, dan lainnya sebesar 8.932,03 Ha. Jumlah total luas lahan Kabupaten Sleman adalah 57.482,50 Ha (BPS, 2015).

\section{Perkembangan Alih Fungsi Lahan Sawah ke Non Sawah}

Penurunan luas lahan pertanian yang terjadi di Kabupaten Sleman sebagian besar merupakan peralihan penggunaan lahan pertanian khususnya lahan sawah ke penggunaan lahan non sawah.Luas lahan sawah di Kabupaten Sleman periode 1984-2013 mengalami penurunan sebesar $4.496 \mathrm{Ha}$ atau $149,866 \mathrm{Ha}$ per tahun. Setiap tahunnya luas lahan sawah berkurang akibat pemanfaatan lahan untuk kepentingan non pertanian, seperti untuk kepentingan pembangunan residential dan industri.

\section{Pertumbuhan Luas Lahan Sawah}

Tabel 1. menunjukkan bahwa di Kabupaten Sleman terjadi alih fungsi lahan sawah. Luas lahan sawah mengalami penurunan dari tahun ke tahun dengan tingkat pertumbuhan sebesar $0,608 \%$ per tahun. Kondisi tersebut diakibatkan oleh pembangunan daerah kearah perkotaan seperti yang tertera pada RTRW Kabupaten Sleman. Pembangunan daerah kearah perkotaan membutuhkan lahan, sering kali lahan yang digunakan adalah lahan sawah karena memiliki land rent yang rendah.

Posisi strategis Kabupaten Sleman menyebabkan pesatnya peningkatan permintaan lahan untuk pembangunan. Kabupaten Sleman memiliki banyak fasilitas pendidikan. Ada 487 sekolah dan 7 perguruan negeri di Kabupaten Sleman (BPS, 2014). Fasilitas pendidikan yang ada dapat meningkatkan jumlah penduduk dalam jumlah banyak, khususnya penduduk dari luar Kabupaten Sleman. Dampak dari banyak pendatang dari luar Kabupaten Sleman salah satunya adalah permintaan pembangunan tempat tinggal baik untuk jangka waktu pendek maupun panjang. Pemenuhan kebutuhan akan tempat tinggal berbanding lurus dengan permintaan lahan yang sering kali adalah lahan sawah karena faktor ketersediaan dan faktor land rent lahan sawah yang cenderung rendah.

Hasil Analisis Faktor yang Mempengaruhi Alih Fungsi Lahan Sawah ke Non Sawah

Alih fungsi lahan pertanian terjadi karena faktor eksternal, internal, dan kebijakan pemerintah (Kustiwan dalam Harini, 2012). 
Faktor yang dianalisis dalam penelitian ini adalah faktor eksternal dan kebijakan pemerintah.Faktor eksternal meliputi faktor dinamika pertumbuhan perkotaan, baik secara spasial, demografis, maupun ekonomi yang memacu atau mendorong terjadinya alih fungsi lahan pertanian.Faktor eksternal ini berkaitan dengan pengembangan kawasan terbangun, pertumbuhan penduduk perkotaan, dan pertumbuhan Pendapatan Regional Bruto (PDRB). Faktor kebijakan merupakan suatu kebjakan yang disatu pihak memacu alih fungsi lahan pertanian dan lain pihak mencegah terjadinya alih fungsi lahan pertanian.

Transformasi struktur perekonomian yang mengarah pada peningkatan peranan sektor industri dan jasa mengubah besaran dan laju penggunaan faktor produksi seperti tenaga kerja, modal, dan lahan antar sektor. Pertumbuhan penduduk yang terus meningkat membawa konsekuensi terhadap perubahan alokasi sumber daya lahan antar sektor, di mana relokasinya lebih diprioritaskan kepada penggunaan yang memiliki rate of return (nilai pengembalian lahan) yang tertinggi yaitu seperti penggunaan lahan untuk kegiatan industri sebagai kegiatan utama yang dapat menarik perkembangan kegiatan lain seperti pemukiman, perdagangan, dan sarana prasarana yang lain sehingga alih fungsi lahan pun tak dapat dielakkan.
Analisis terhadap faktor-faktor yang mempengaruhi luas lahan sawah di Kabupaten Sleman diolah dengan program SPSS versi 16.0. Hasil estimasi faktor-faktor yang mempengaruhi alih fungsi lahan sawah ke non sawah ditunjukkan pada Tabel 2.

Koefisien determinasi $\left(\mathrm{R}^{2}\right)$ dari fungsi dugaan mencapai 0,955. Hal ini menunjukkan bahwa variabel independen yang dimasukkan dalam model mampu menerangkan perilaku (keragaman) variabel dependen alih fungsi lahan sawah ke non sawah di Kabupaten Sleman sebesar $95,5 \%$ dan sisanya sebesar $4,5 \%$ dipengaruhi oleh variabel lain di luar faktor-faktor yang diteliti di dalam penelitian.

Uji $F$ di dalam persamaan model bertujuan untuk mengetahui variabel-variabel independen yang secara bersamaan berpengaruh nyata terhadap alih fungsi lahan sawah ke non sawah. Nilai konstanta (intersep) sebesar 16,686 menyatakan bahwa jika terdapat variabelvariabel independen seperti jumlah penduduk, jumlah industri, jumlah residential, panjang jalan, Pendapatan Domestik Regional Bruto (PDRB), serta kebijakan pemerintah, maka alih fungsi lahan sawah ke non sawah akan bertambah sebesar 16,686 persen. Hasil uji $\mathrm{F}$ pada Tabel 2. menunjukkan nilai sebesar 0,000 yang berarti $\mathrm{H}_{0}$ ditolak pada taraf uji 0,05 .

Tabel 2. Hasil Regresi Faktor-Faktor yang Mempengaruhi Perubahan Luas Lahan Sawah ke Non Sawah di Kabupaten Sleman Tahun 1984-2013

\begin{tabular}{|c|c|c|c|}
\hline No & Variabel Penjelas & Koefisien Regresi & Sig t \\
\hline 1. & Intersep & 16,686 & \\
\hline 2. & Penduduk & $-0,100 * * *$ & 0,003 \\
\hline 3. & Industri & $-1,282 * *$ & 0,021 \\
\hline 4. & Residential & $-0,573 * * *$ & 0,001 \\
\hline 5. & Panjang Jalan & $0,271^{\mathrm{ns}}$ & 0,115 \\
\hline 6. & PDRB & $-0,795^{*}$ & 0,054 \\
\hline 7. & Dummy (Kebijakan Pemerintah) & $-0,280^{\mathrm{ns}}$ & 0,234 \\
\hline \multicolumn{2}{|c|}{ Koefisien Determinasi $\left(\mathrm{R}^{2}\right)$} & 0,955 & \\
\hline \multicolumn{2}{|c|}{ F-hitung } & 0,000 & \\
\hline \multicolumn{2}{|c|}{ Durbin Watson } & 2,052 & \\
\hline \multicolumn{2}{|c|}{ Periode Sampel } & $1984-2013$ & \\
\hline \multicolumn{2}{|c|}{$\mathrm{N}$} & 30 & \\
\hline
\end{tabular}

Sumber: Data Sekunder (terlampir)

Keterangan : $* \quad=$ nyata pada tingkat kepercayaan $90 \%$

$* * \quad=$ nyata pada tingkat kepercayaan $95 \%$

*** = nyata pada tingkat kepercayaan $99 \%$

ns $\quad=$ non significant (tidak signifikan) 
Hal ini berati secara bersama-sama seluruh variabel independen berpengaruh terhadap alih fungsi lahan sawah ke non sawah nyata pada tingkat kepercayaan $95 \%$.

Uji $t$ di dalam persamaan model bertujuan untuk mengetahui masing-masing variabel independen yang secara individu berpengaruh nyata terhadap alih fungsi lahan sawah ke non sawah. Berdasarkan Tabel 2. Hasil uji $\mathrm{t}$ variabel jumlah penduduk, jumlah industri, jumlah residential, dan PDRB merupakan variabel independen yang menentukan alih fungsi lahan sawah dan berpengaruh nyata secara individu pada taraf $\alpha$ $=0,05$. Dua variabel lain, yaitu panjang jalan, dan kebijakan pemerintah tidak berpengaruh nyata terhadap alih fungsi lahan sawah ke non sawah.

Jumlah penduduk memiliki nilai signifikansi sebesar 0,003. Artinya, secara parsial variabel jumlah penduduk berpengaruh nyata pada tingkat kepercayaan $95 \%$ terhadap perubahan luas lahan sawah di Kabupaten Sleman. Variabel jumlah penduduk berpengaruh negatif terhadap variabel dependen. Menunjukkan setiap penambahan jumlah penduduk sebesar $1 \%$ maka akan mengurangi luas lahan sawah sebesar $0,1 \%$. Merujuk pada

Jumlah penduduk yang ada di Kabupaten Sleman setiap tahun mengalami peningkatan dengan kata lain jumlah kelahiran (natalitas) lebih besar dari pada jumlah kematian (mortalitas). Jumlah penduduk yang bertambah sangat membutuhkan rumah tempat tinggal atau pemukiman-pemukiman baru untuk tempat tinggal. Pembangunan pemukiman yang merupakan dampak dari penambahan jumlah penduduk secara langsung akan mengurangi jumlah lahan pertanian khususnya lahan sawah, akan tetapi hasil analisis menunjukkan bahwa pertambahan jumlah penduduk di Kabupaten Sleman berpengaruh negatif terhadap alih fungsi lahan sawah ke non sawah.

Jumlah industri memiliki nilai signifikansi sebesar 0,021. Artinya, secara parsial variabel jumlah penduduk berpengaruh nyata pada tingkat kepercayaan $95 \%$ terhadap perubahan luas lahan sawah di Kabupaten Sleman. Variabel jumlah industri berpengaruh negatif terhadap variabel dependen. Hal ini menunjukkan setiap penambahan jumlah industri sebesar $1 \%$ maka akan mengurangi luas lahan sawah sebesar 1,282\%.

Sektor industri banyak berkembang di kabupaten Sleman. Periode 1984-2013 industri berkembang pesat terutama industri kecil. Lahan dibutuhkan untuk memenuhi perkembangan baik industri kecil maupun industri besar menengah. Semakin banyak industri semakin banyak luas lahan sawah yang berkurang.

Jumlah residential memiliki nilai signifikansi sebesar 0,001. Artinya, secara parsial variabel jumlah penduduk berpengaruh nyata pada tingkat kepercayaan $95 \%$ terhadap perubahan luas lahan sawah di Kabupaten Sleman. Menunjukkan setiap penambahan jumlah residential sebesar $1 \%$ maka akan mengurangi luas lahan sawah sebesar $0,573 \%$.

Jumlah residential yang terus meningkat menyebabkan permintaan akan lahan pun meningkat. Sering kali lahan yang digunakan untuk mendirikan residential adalah lahan sawah. Semakin banyak residential yang didirikan akan semakin berkurang luas lahan sawah di Kabupatem Sleman.

Variabel panjang jalan memiliki nilai signifikansi sebesar 0,115. Secara parsial variabel ini tidak signifikan terhadap variabel dependen. Selama 3 dekade pertumbuhan pembangunan jalan di Kabupaten Sleman hanya sebesar 19,85 km, sehingga walaupun tejadi pertambahan panjang jalan tidak berpengaruh signifikan teradap perubahan luas lahan sawah di Kabupaten Sleman.

Variabel PDRB memiliki nilai signifikansi sebesar 0,054. Secara parsial variabel PDRB berpengaruh nyata pada tingkat kepercayaan $99 \%$ terhadap penurunan luas lahan sawah di Kabupaten Sleman. Berdasarkan Tabel 2. didapatkan hasil koefisien PDRB sebesar 0,795. Hal ini dapat diartikan bahwa peningkatan PDRB sebesar 1\% akan mengurangi luas lahan sawah sebesar $0,795 \%$.

Kondisi ini mencerminkan bahwa alih fungsi lahan sawah ke non sawah merupakan dampak dari peningkatan Pendapatan Domestik Regional Bruto (PDRB). Peningkatan Pendapatan Domestik Regional Bruto (PDRB) di satu sisi membawa dampak positif bagi kesejahteraan masyarakat tetapi di sisi lain berdampak negatif karena memicu terjadinya alih fungsi lahan sawah ke non sawah. Alih 
fungsi lahan sawah ke non sawah merupakan dampak negatif dalam upaya meningkatkan kesejahteraan masyarakat yang tidak dapat dihindari.

Berdasarkan Tabel 2. dapat dilihat bahwa variabel dummy kebijakan pemerintah memiliki nilai signifikansi 0,234. Artinya variabel kebijakan pemerintah tidak signifikan berpengaruh terhadap alih fungsi lahan sawah ke non sawah di Kabupaten Sleman.

Peraturan Pemerintah UU No. 16 Tahun 2004 direalisasikan melalui RTRW Kabupaten Sleman. Di dalam RTRW tersebut terdapat kebijakan pro dan kontra terhadap pertanian. Di satu sisi diterangkan dalam RTRW Kabupaten Sleman ada daerah-daerah tertentu merupakan lumbung padi dan sawah yang beririgrasi tidak diperbolehkan dialihfungsikan. Di sisi lain demi menunjang kesejahteraan masyarakat, salah satu alternatif yang diambil pemerintah adalah memperkuat sektor non pertanian seperti sektor industri, jasa, serta perdagangan.

\section{KESIMPULAN DAN SARAN}

\section{Kesimpulan}

Kesimpulan yang dapat diambil dari penelitian dan analisis mengenai faktor-faktor yang mempengaruhi alih fungsi lahan sawah ke non sawah di Kabupaten Sleman adalah:

1. Berdasarkan analisis data luas lahan sawah selama kurun waktu 30 tahun terjadi alih fungsi lahan sawah ke non sawah di Kabupaten Sleman. Luas lahan sawah yang beralihfungsi pada periode 1984-2013 adalah sebesar $4.496 \mathrm{Ha}$ atau 149,866 $\mathrm{Ha}$ per tahun.

2. Luas lahan sawah di Kabupaten Sleman mengalami penurunan dari tahun ke tahun dengan tingkat penurunan $0,608 \%$ per tahun.

3. Faktor-faktor yang mempengaruhi alih fungsi lahan sawah ke non sawah di Kabupaten Sleman tahun 1984-2013 adalah jumlah penduduk, jumlah industri, jumlah residential, dan PDRB.

\section{Saran}

Alih fungsi lahan dapat dikendalikan dengan sikap tegas dari berbagai pihak terkait yaitu pengguna lahan baik pemlik maupun pemangku kepentingan dan lembaga pemerintahan seperti kelurahan, kecamatan, pemerintah daerah,
BPN, dan Dinas Pertanian. Perlu adanya peninjauan ulang dan memperkuat kebijakan RTRW (Rencana Tata Ruang dan Wilayah) sehingga mampu mengendalikan alih fungsi lahan pertanian khususnya lahan sawah serta menindaklanjuti dengan melakukan pengawasan, pengontrolan, dan pengendalian terhadap segala proses perubahan penggunaan lahan yang dilakukan oleh pelaku perubah maupun terhadap alih fungsi lahan sawah yang tidak sesuai dengan Rencana Tata Ruang dan Wilayah agar bisa menekan atau memperkecil alih fungsi lahan sawah ke non sawah di Kabupaten Sleman.

\section{DAFTAR PUSTAKA}

Bachriadi, D. Faryadi, E. Setiawan, B. 1997. Reformasi Agraria: Politik, Sengketa, dan Agenda Pembaharuan Agraria di Indonesia. Fakultas Ekonomi Universitas Indonesia. Jakarta.

BPS.2014. Kabupaten Sleman dalam Angka. Badan Pusat Statistik Sleman. Sleman.

2015. Indonesia dalam Angka. Badan Pusat Statistik Indonesia. Jakarta.

Ghozali, I. 2011. Analisis Multivariate dengan program IBM SPSS. Universitas Diponegoro. Semarang.

Harini, R. 2012. Kajian Spasial Valuasi ekonomi Lahan Pertanian Terkonversi dan Dampaknya terhadap produksi Pangan di Kabupaten Sleman. Tesis. Universitas Gadjah mada.Yogyakarta.

Irawan, B. 2005. Konversi Lahan Sawah: Potensi Dampak Pola Pemanfaatannya dan Faktor Determinan. Forum Penelitian Agro Ekonomi Vol. 23 No.1 Juli 2005 Hal 1-18. Pusat Penelitian dan Pengembangan Sosial Ekonomi Pertanian.

Nazir, M. 2003. Metode Penelitian. Ghalia Indonesia. Jakarta.

Sjafrizal.2004. Perencanaan Pembangunan Daerah dalam Otonomi. Raja Grafindo. Depok.

Surakhmad, W. 2004. Pengantar Penelitian Ilmiah-ilmiah Dasar. Penerbit: Tarsito. Bandung. 